\title{
Азот и фосфор в центральной зоне озера Арахлей
}

\author{
М.О. Морозова $\bowtie$ \\ ФГБУН «Институт природных ресурсов, экологии и криологии \\ Сибирского отделения Российской академии наук», Российская Федераџия \\ (672014, г. Чита, ул. Недорезова, 16A)
}

\begin{abstract}
Аннотация: Цель: на основе экспедиционных исследований озера Арахлей показать изменение содержания биогенных элементов (азот и фосфор) с 2017 по 2019 год. Озеро Арахлей расположено в Восточной части Витимского плоскогорья на водоразделе Витим и Селенга в условиях резко континентального климата. Входит в группу озер Ивано-Арахлейской системы.

Mатериалы и методы. При отборе проб и их анализе использовали стандартные гидрохимические методы и ГОСТ. Исследования проводили с использованием спектрофотометра Spekol-1300.

Результаты и обсуждение. В сравнении с 2017 и 2019 годами в 2018 году в озере Арахлей произошло повышение концентрации биогенных элементов, что связано с увеличением количества осадков в летнее время. Окисляемость органического вещества в поверхностных водах подвержена значительным и довольно закономерным колебаниям, как в течение года, так и на протяжении нескольких лет. Это определяется изменением во времени и минерализации как аллохтонного, так и автохтонного органического вещества, накопленного в водоеме.

Заключение. Увеличение нитрат-ионов, фосфатов и общего фосфора связанно с обильными атмосферными осадками, повлиявшими на увеличение поступления аллохтонного органического вещества. Биогенные элементы, в основном, находятся в пределах нормы ПДК определено, что содержание органического вещества почти не изменилось за весь исследуемый промежуток времени (2017 - 2019 гг.).
\end{abstract}

Ключевые слова: азот, фосфор, биогенные элементы, осадки, поверхностные воды, органическое вещество, изменение климата, эвтрофирование.

Для цитирования: Морозова М.О. Азот и фосфор в центральной зоне озера Арахлей // Вестник Воронежского государственного университета. Серия: География, Геоэкология, 2021, № 2, с. 38-43. DOI: https://doi.org/10.17308/geo.2021.2/3445

\section{ВВЕДЕНИЕ}

Озеро Арахлей расположено в Восточной части Витимского плоскогорья на водоразделе рек Витим и Селенга. Входит в группу озер ИваноАрахлейской системы. Абсолютная высота дна озера 960-980 м над уровнем моря. Площадь водосбора - 256 км². Площадь водной поверхности - 59 км², максимальная глубина в многоводные годы - 17 м [14], а средняя в период наших исследований - 13,5 м. Химический состав воды формируется за счет притока в озеро поверхностных вод и за счет внутриводоемных процессов образования и разложения органических веществ [6]. Также влияние оказывает и количество осадков в условиях резко континентального климата Забай- калья, что отражается на колебании уровня озера, и, как следствие, на поступлении в водоем биогенных элементов.

В химический состав воды входят биогенные элементы, которые определяют среду обитания гидробионтов, биологическую продуктивность водоемов, служат показателями загрязнения воды. Одни из главных биогенных элементов в воде - это азот и фосфор. Азот регулирует жизнедеятельность растений. Фосфор является лимитирующим фактором развития фитопланктона. Установлено, что изучение данных элементов в водных экосистемах играет важную роль в прогнозировании процессов эвтрофирования [9, 11, 13]. В связи с вышесказанным, гидрохимическое состояние озера Арахлей

(C) Морозова М.О., 2021

$\triangle$ Марина Олеговна Морозова, e-mail: marina_matveeva_94@inbox.ru

Контент доступен под лицензией Creative Commons Attribution 4.0 License. 
в разные промежутки времени относится к актуальной задаче экологических исследований.

Цель нашего анализа - сравнение межгодового содержания азота и фосфора в воде центральной зоны озера Арахлей с 2017 по 2019 годы.

\section{МАТЕРИАЛЫ И МЕТОДЫ}

Содержание азота и фосфора в воде озера основано на результатах полевых исследований, проведенных с 2017 по 2019 год сотрудниками лаборатории водных экосистем ИПРЭК СО РАН $[7,15]$. Отбор проб в озере Арахлей проводили в центральной (геометрический центр водоема) зоне озера $\left(52^{\circ} 12.3595^{\prime} \mathrm{N} ; 112^{\circ} 50.0044^{\prime} \mathrm{E}\right)$ в пластиковые бутылки объемом 1 л. При отборе проб и их анализе использовали стандартные гидрохимические методы [17] и ГОСТ [2]. Исследования проводили с использованием спектрофотометра Spekol-1300. Отобрано и проанализировано 60 проб воды в разные промежутки времени.

Полученные результаты были сопоставлены с нормативами качества воды объектов рыбохозяйственного назначения (ПДК ${ }_{\mathrm{p} / \mathrm{x}}$ ) (таблица).

Таблицุа

Нормативы качества воды водных объектов рыбохозяйственного значения (ПДК

[Table. Water quality standards for water bodies of fishery significance $\left(\mathrm{Mpc}_{\mathrm{r} / \mathrm{x}}\right)$ ]

\begin{tabular}{|c|c|}
\hline Загрязняющее вещество / Pollutant & ПДК ${ }_{p / x}, \mathrm{мг} /$ Дм $^{3} / \mathrm{Mpc}_{\mathrm{r} / \mathrm{x}}, \mathrm{mg} / \mathrm{dm}^{3}$ \\
\hline Нитрит - ион $\left(\mathrm{NO}_{2}^{-}\right) /$Nitrite ion $\left(\mathrm{NO}_{2}^{-}\right)$ & 0,08 \\
\hline Нитрат - ион $\left(\mathrm{NO}_{3}^{-}\right) /$Nitrate ion $\left(\mathrm{NO}_{3}^{-}\right)$ & 40 \\
\hline $\begin{array}{c}\text { Аммонийный азот }\left(\mathrm{NH}_{4}^{+}\right) / \text {Ammonium nitrogen } \\
\left(\mathrm{NH}_{4}^{+}\right)\end{array}$ & 0,51 \\
\hline Фосфаты $\left(\mathrm{PO}_{4}^{3-}\right) /$ Phosphates $\left(\mathrm{PO}_{4}^{3-}\right)$ & $\begin{array}{c}0,15 \text { (мезотрофный водоем) / (mesotrophic } \\
\text { reservoir) }\end{array}$ \\
\hline $\begin{array}{l}\text { Общий фосфор }\left(\mathrm{P}_{\text {обш }}\right) / \\
\text { Total phosphorus }\left(\mathrm{P}_{\text {total }}\right)\end{array}$ & 0,066 \\
\hline
\end{tabular}

\section{РЕЗУЛЬТАТЫ И ОБСУЖДЕНИЕ}

В водоеме минеральный азот содержится в трех формах - аммонийной, нитритной и нитратной, представляющих последовательные степени окисления [1]. На рисунке 1 показаны результаты по среднему содержанию нитритов, нитратов и ионов аммония за три года исследований (2017, 2018 и 2019) в центральной зоне озера Арахлей.

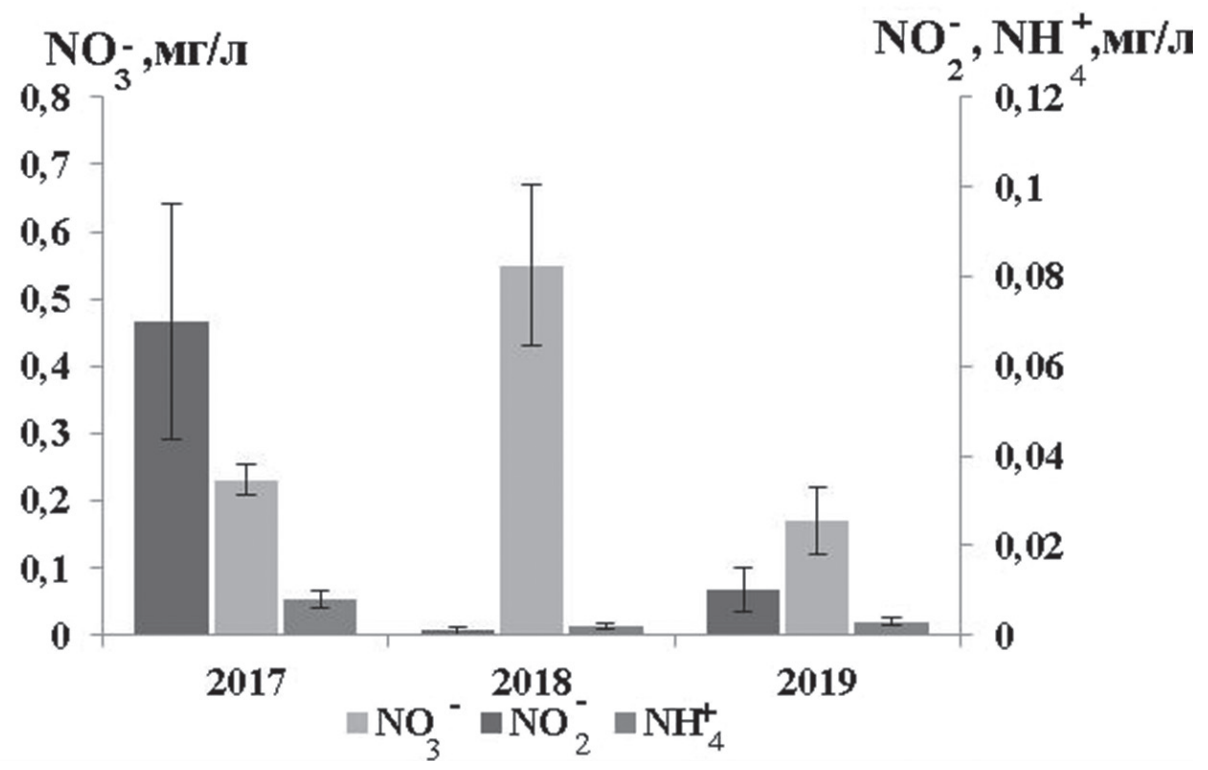

Puc. 1. Изменение содержания нитритов, нитратов и ионов аммония в центральной зоне озера Арахлей 2017-2019 годы [Fig. 1. Changes in the content of nitrites, nitrates, and ammonium ions in the Central zone of the Arakhley Lake 2017-2019]

Концентрация нитратного азота в 2018 году по сравнению с 2017 и 2019 годом увеличивается почти на 0,6 мг/л, что обуславливается обильным выпадением осадков в летнее время и поступлением аллохтонного органического вещества.
Начиная с 2017 года, получен широкий диапазон значений нитритного азота от 0,001 мг/л до 0,07 мг/л в течение всего периода исследований. Нитриты - промежуточные продукты биологического разложения азотсодержащих органических 
веществ [6]. Изменение концентрации нитритов зависит от интенсивности процессов денитрификации и нитрификации [8]. Высокая скорость нитрификации способствует снижению содержания нитритного азота в водоеме [14].

Диапазон изменения содержания ионов аммония находится в пределах0,002-0,008 мг/л. Следовательно, за время исследования колебания незначительные. Присутствие аммонийного азота в воде связано с процессами разложения белковых веществ и восстановлением нитратов и нитритов. Низкая концентрация аммонийного азота объясняется его потреблением автотрофами и нитрифицирующими микроорганизмами [1]. Из-за высокой скорости окисления аммонийных ионов их концентрация подвержена снижению [12].

Фосфор, как и азот, является одним из главных биогенных элементов. На рисунке 2 показаны результаты по содержанию фосфатов и общего фосфора в водоеме.

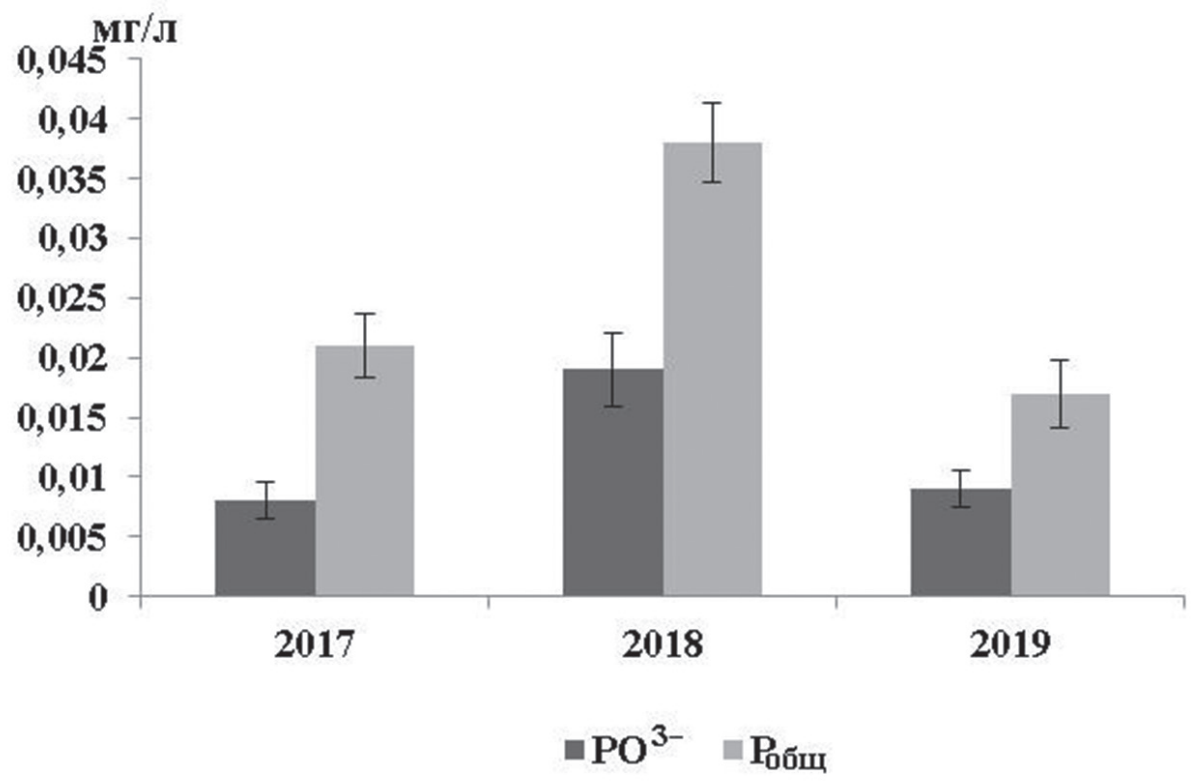

Puc. 2. Изменение концентрации фосфатов и общего фосфора в центральной зоне озера Арахлей [Fig. 2. Changes in the concentration of phosphates and total phosphorus in the Central zone of the Arakhley Lake]

Кроме внутриводоемных процессов фосфор в экосистему поступает с поверхностным стоком с водосборной площади [1]. Наличие и изменение содержания фосфатов и общего фосфора в воде озера (рис. 3) указывает на способность экосистемы к биохимическому разложению органического вещества и последующей его трансформации по трофической цепи [16]. Содержание соединений фосфора подвержено значительным колебаниям, поскольку зависит от соотношения интенсивности процессов фотосинтеза и биохимического разложения веществ. При быстром темпе возрастания концентраций биогенных элементов (азот и фосфор) может возникнуть процесс эвтрофикации.

Содержание фосфатов в озере изменяется от 0,008 до 0,019 мг/л. Увеличение концентрации произошло в 2018 году и достигло 0,019 мг/л, что связано с обильным выпадением осадков в летнее время и поступлением фосфатов с водосборной площади.

Концентрация общего фосфора в озере колеблется от 0,017 мг/л до 0,038 мг/л. К 2018 году его концентрация также увеличилась и составила 0,038 мг/л, что связано с ростом количества осадков и поступлением аллохтонного органического вещества. Наши результаты сопоставимы с данными других исследователей [1].

Сравнивая содержание азота и фосфора в озере Арахлей с нормативами качества воды объектов рыбохозяйственного назначения (ПДК ${ }_{p / x}$ ), было установлено, что содержание нитритов в 2017 году приближено к ПДК

Концентрации аммонийного азота, нитрат иона и содержание фосфатов и общего фосфора находятся в пределах нормы ПДК тельствует о низкой тенденции процесса эвтрофирования или вовсе об ее отсутствии.

Ниже (рис. 3) представлены данные по динамике органического вещества в озере, определенного по перманганатной (ПО) и бихроматной окисляемости (ХПК).

Пределы изменений концентраций перманганатной окисляемости от 3 до 6 мг/л и бихроматной окисляемости от 12 до 15 мг/л по всем исследуе- 


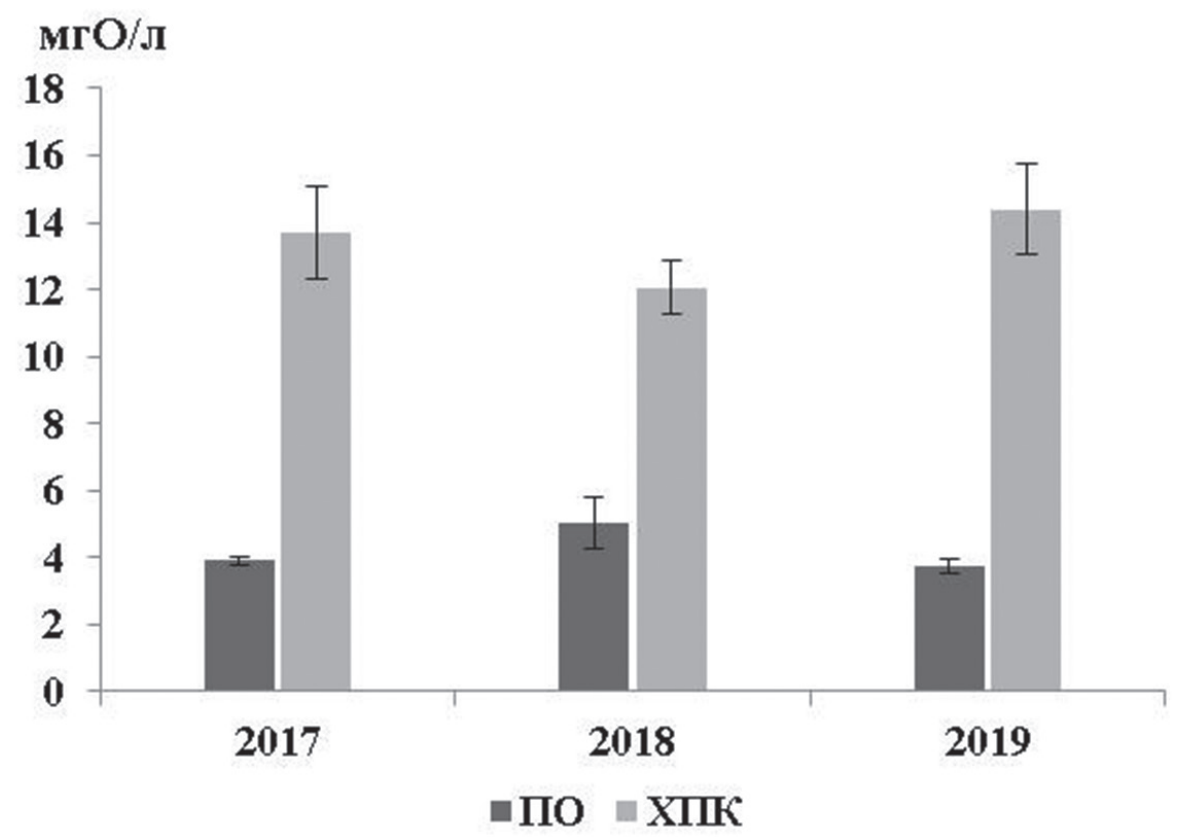

Puc. 3. Изменение концентрации ПО и ХПК в центральной зоне озера Арахлей

[Fig. 3. Changes in the concentration of PO and COD in the Central zone of the Arakhley Lake]

мым годам. Окисляемость органического вещества в поверхностных водах обычно подвержена значительным и довольно закономерным колебаниям. Это определяется изменением во времени и минерализации как аллохтонного, так и автохтонного органического вещества, накопленного в водоеме. О доминировании аллохтонного или автохтонного органического вещества, присутствующего в водоеме, судят по соотношению ПО к ХПК [3]. В нашем случае органическое вещество в озере автохтонного происхождения, т.к. это соотношение меньше 50 \%.

\section{ЗАКЛЮЧЕНИЕ}

В результате проведенных исследований установлено, что нитритный азот и аммонийные ионы имеют достоверную тенденцию уменьшения концентрации с 2017 к 2019 году. В 2018 году произошло увеличение нитрат-ионов, фосфатов и общего фосфора, связанное с обильным выпадением атмосферных осадков, повлиявших на увеличение поступления аллохтонного органического вещества. Сравнение содержания азота и фосфора в озере Арахлей с нормативами качества воды объектов рыбохозяйственного назначения $\left(\right.$ ПДК $\left.{ }_{p / x}\right)$ выявило, что концентрация нитритов в 2017 году приближена к ПДК и составила 0,07 мг/л. Остальные биогенные элементы также находятся в пределах нормы ПДК ${ }_{\mathrm{p} / \mathrm{x}}$.

Концентрации как легкоокисляемого органического вещества, так и трудноокисляемого органического вещества практически не изменяются за время наших исследований.

\section{СПИСОК ЛИТЕРАТУРЫ}

1. Вецлер Н. М. Биогенный режим озера Саранного (остров Беринга, Командоры) в 2001-2012 гг. // Исследования водных биологических ресурсов Камчатки и Северо-Западной части Тихого океана, 2016, №40, с. 78-86.

2. ГОСТ 33045-2014. Межгосударственный стандарт. Вода. Методы определения азотсодержащих веществ [Текст]. - Взамен ГОСТ 4192-82; введ. 2016-0101. М.: Межгос. совет по стандартизации, метрологии и сертификации. Москва: Изд-во стандартов, 2016. 21 с.

3. Зобкова М.В. Характеристика автохтонного и аллохтонного органического вещества с использованием их отличительных признаков // Tpуды VI Bсероссийского симпозиума с международным участием (28 августа - 1 сентября 2017 г., Барнаул), 2017, с. 97-103.

4. Ивано-Арахлейские озера на рубеже веков. Состояние и динамика. Новосибирск: Издательство СО PAH, 2013. $337 \mathrm{c}$.

5. Котов В.В., Нетесова Г.А. Химия и микробиология воды. Воронеж: ФГОУ ВПО ВГАУ, 2008. 320 с.

6. Маслова М.О., Прожорина Т.И., Якунина Н.И. Эколого-аналитическая оценка качества вод рекреационных зон Ближнего Подворонежья // Вестник Воронежского государственного университета. Серия: География. Геоэкология, 2014, № 4, с. 48-56.

7. Матвеева М.О. Внутригодовая динамика азота и фосфора в литоральной и центральной зонах озера Арахлей за 2018 г. // Проблемы устойчивого развития региона, 2019, с. 135-139.

8. Особенности гидрохимии эустариев рек Артемовки и Шкотовки (Уссурийский залив, Японское море) летом 2011 г. // Известия ТИНРО, 2012, т. 171, с. 267-284.

9. Русанов Г. Г. Экологические проблемы Колыванского озера и его окрестностей // Известия Алтайского 
отделения Русского Географического общества, 2016, № 2 (41), с. 56-64.

10. Семенов А.Д. Руководство по химическому анализу поверхностных вод суши. Ленинград: Гидрометеоиздат, 1977. $541 \mathrm{c.}$

11. Сиделев С.И. Экспериментальное изучение влияния биогенных элементов на фитопланктон мелководного высокоэвтрофного озера Неро // Биология внутренних вод, 2012, № 1, с. 60-66.

12. Уколова Т.К. Сезонная динамика биогенных элементов в озере Курильском в 2005 г. // Исследования водных биологических ресурсов Камчатки и Северо-Западной части Тихого океана, 2009, № 15, с. 5-20.

13. Фрумин Г. Т. Динамика содержания биогенных элементов в озере Тайху // Экологическая химия, 2012, т. 21, № 2, c. 74-80.

14. Цыбекмитова Г.Ц. Динамика биогенных элементов в воде озера Арахлей // География и природные ресурсы, 2012, № 1, с. 155-158.

15. Цыбекмитова Г.Ц., Матвеева М. О. Содержание биогенных элементов в озерах Онон-Торейской котло- вины в период климатических флуктуаций // Водное хозяйство, 2019, № 3, с. 94-109.

16. Цыбекмитова Г.Ц. Современное состояние озера Арахлей // Tруды VII Всероссийской научно-практической конференции с международным участием «Современные проблемы водохранилищ и их водосборов», 2019, с. 90-94.

17. Adamovich B.V., Nikitina L.V., Mikheeva T.M. Kovalevskaya R.Z., Veres Y.K., Zhukova T. V., Medvinsky A.B., Rusakov A.V., Nurieva N.I., Radchikova N.P., Chakraborty A. Relations between variations in the lake bacterioplankton abundance and the lake trophic state: evidence from the 20-year monitoring // Ecological Indicators, 2019, vol. 97, pp. 120-129.

Конфликт интересов: Автор декларирует отсутствие явных и потенциальных конфликтов интересов, связанных с публикацией настоящей статьи.

Поступила в редакцию 24.08.2020 Принята к публикаџии 28.05.2021

\title{
Nitrogen and Phosphorus in the Central Zone of the Arakhley Lake
}

\author{
M.O. Morozova $\bowtie$ \\ FSBIS Institute of Natural Resources, Ecology and Cryology of the Siberian Branch \\ of the Russian Academy of Sciences, Russian Federation \\ (16A, Nedorezov St., Chita, 672014)
}

\begin{abstract}
The aim is to show changes in the content of biogenic elements (nitrogen and phosphorus) in the Arakhley Lake, observed during the field research from 2017 to 2019. The Arakhley Lake is located in the Eastern part of the Vitim plateau on the watershed of the Vitim and the Selenga rivers, in the area featuring a sharply continental climate. The Arakhley Lake belongs to the system of the Ivano-Arakhleysky Lakes.

Materials and methods. Standard hydrochemical methods and GOST were used in sampling and analysis. The studies were carried out using a Spekol-1300 spectrophotometer.

Results and discussion. In 2018, as compared to the findings of 2017 and 2019, the concentration of biogenic elements in the Arakhley Lake increased due to the increase in precipitation in the summer. The oxidability of organic matter in surface waters features significant and fairly regular fluctuations detected over a year and during a long-term period. Those are determined by the change in time and mineralization of both allochthonous and autochthonous organic matter accumulated in the reservoir.

Conclusions. The research has shown that the increase nitrate ions, phosphates and total phosphorus is associated with heavy precipitation, which caused an increase in the intake of allochthonous organic matter. Biogenic elements are mostly within the normal range of $\mathrm{MPC}_{\mathrm{r} h \mathrm{~h}}$. The content of organic matter showed no significant changes over the entire study period (2017-2019).
\end{abstract}

Key words: nitrogen, phosphorus, biogenic elements, precipitation, surface waters, organic matter, climate change, eutrophication.

(C) Morozova M. O., 2021

$\triangle$ Marina O. Morozova, e-mail: marina_matveeva_94@inbox.ru

(c) (i) The content is available under Creative Commons Attribution 4.0 License. 
For citation: Morozova M. O. Nitrogen and Phosphorus in the Central Zone of the Arakhley Lake. Vestnik Voronezskogo gosudarstvennogo universiteta. Seria: Geografia. Geoekologia, 2021, no. 2, pp. 38-43. (In Russ.). DOI: https://doi.org/10.17308/geo.2021.2/3445

\section{REFERENCES}

1. Vetsler N.M. Biogennyy rezhim ozera Sarannogo (ostrov Beringa, Komandory) v 2001-2012 gg. [Biogenic mode of Lake Sarahnaya (Bering Island, Commmors) in 2001-2012]. Issledovaniya vodnykh biologicheskikh resursov Kamchatki i Severo-Zapadnoy chasti Tikhogo okeana, 2016, no. 40, pp. 78-86. (In Russ.)

2. GOST 33045-2014. Mezhgosudarstvennyy standart. Voda. Metody opredeleniya azotsoderzhashchikh veshchestv [GOST 33045-2014. Interstate standard. Water. Methods for determining nitrogen-containing substances] [Tekst]. - Vzamen GOST 4192-82; vved. 2016-01-01. M.: Mezhgos. sovet po standartizatsii, metrologii i sertifikatsii. Moskva: Izd-vo standartov, 2016. 21 p. (In Russ.)

3. Zobkova M. V. Kharakteristika avtokhtonnogo i allokhtonnogo organicheskogo veshchestva s ispol'zovaniem ikh otlichitel'nykh priznakov [Characteristics of authon and alchtonic organic matter using their distinctive features]. Trudy VI Vserossiyskogo simpoziuma s mezhdunarodnym uchastiem (28 avgusta - 1 sentyabrya 2017 g., Barnaul), 2017, pp. 97-103. (In Russ.)

4. Ivano-Arakhleyskie ozera na rubezhe vekov. Sostoyanie $i$ dinamika [Ivano-Arachleh lakes at the turn of the century. Condition and dynamics]. Novosibirsk: Izdatel'stvo SO RAN, 2013. 337 p. (In Russ.)

5. Kotov V.V., Netesova G.A. Khimiya i mikrobiologiya vody [Chemistry and microbiology of water]. Voronezh: FGOU VPO VGAU, 2008. 320 p. (In Russ.)

6. Maslova M.O., Prozhorina T.I., Yakunina N.I. Ekologo-analiticheskaya otsenka kachestva vod rekreatsionnykh zon Blizhnego Podvoronezh'ya [Ecological and analytical assessment of the quality of waters in the recreational zones of the Near Voronezh]. Vestnik Voronezhskogo gosudarstvennogo universiteta. Seria: Geografia. Geoekologia, 2014, no. 4, pp. 48-56. (In Russ.)

7. Matveeva M.O. Vnutrigodovaya dinamika azota i fosfora v litoral'noy i tsentral'noy zonakh ozera Arakhley za 2018 g. [Introductory dynamics of nitrogen and phosphorus in the littoral and central zones of Arachlya Lake for 2018]. Problemy ustoychivogo razvitiya regiona, 2019, pp. 135-139. (In Russ.)

8. Osobennosti gidrokhimii eustariev rek Artemovki i Shkotovki (Ussuriyskiy zaliv, Yaponskoe more) letom 2011 g. [Features of the hydrochemistry of Eustares of the Rivers of Artemovki and Skirotki (Ussuri Bay, Japanese Sea) in the summer of 2011]. Izvestiya TINRO, 2012, vol. 171, pp. 267-284. (In Russ.)

9. Rusanov G. G. Ekologicheskie problemy Kolyvanskogo ozera i ego okrestnostey [Environmental problems of the Kolyvan Lake and its surroundings]. Izvestiya Al-

Марина Олеговна Морозова

инженер, аспирант ФГБУН «Институт природных ресурсов, экологии и криологии Сибирского отделения Российской академии наук», г. Чита, Российская Федерация, ORCID: 0000-0001-8152-8285, e-mail: marina matveeva94@inbox.ru tayskogo otdeleniya Russkogo Geograficheskogo obshchestva, 2016, no. 2 (41), pp. 56-64. (In Russ.)

10. Semenov A.D. Rukovodstvo po khimicheskomu analizu poverkhnostnykh vod sushi [Sushi Surface Water Chemical Analysis Guide]. Leningrad: Gidrometeoizdat, 1977. 541 p. (In Russ.)

11. Sidelev S. I. Eksperimental'noe izuchenie vliyaniya biogennykh elementov na fitoplankton melkovodnogo vysokoevtrofnogo ozera Nero [Experimental study of the influence of biogenic elements on phytoplankton shallow high-ewed lake Nero]. Biologiya vnutrennikh vod, 2012, no. 1, pp. 60-66. (In Russ.)

12. Ukolova T.K. Sezonnaya dinamika biogennykh elementov v ozere Kuril'skom v 2005 g. [Seasonal dynamics of biogenic elements in Lake Kurilsky in 2005]. Issledovaniya vodnykh biologicheskikh resursov Kamchatki $i$ Severo-Zapadnoy chasti Tikhogo okeana, 2009, no. 15, pp. 5-20. (In Russ.)

13. Frumin G.T. Dinamika soderzhaniya biogennykh elementov v ozere Taykhu [Dynamics of the content of biogenic elements in Lake Thai]. Ekologicheskaya khimiya, 2012, vol. 21, no. 2, pp. 74-80. (In Russ.)

14. Tsybekmitova G. Ts. Dinamika biogennykh elementov v vode ozera Arakhley [Dynamics of biogenic elements in the water of Lake Arachli]. Geografiya i prirodnye resursy, 2012, no. 1, pp. 155-158. (In Russ.)

15. Tsybekmitova G. Ts., Matveeva M. O. Soderzhanie biogennykh elementov $\mathrm{v}$ ozerakh Onon-Toreyskoy kotloviny $\mathrm{v}$ period klimaticheskikh fluktuatsiy [The content of biogenic elements in the lakes of the ONON-Torean brand during the period of climatic fluctuations]. Vodnoe khozyaystvo, 2019, no. 3, pp. 94-109. (In Russ.)

16. Tsybekmitova G. Ts. Sovremennoe sostoyanie ozera Arakhley [Modern State of Lake Arachli]. Trudy VII Vserossiyskoy nauchno-prakticheskoy konferentsii s mezhdunarodnym uchastiem "Sovremennye problemy vodokhranilishch i ikh vodosborov», 2019, pp. 90-94. (In Russ.)

17. Adamovich B.V., Nikitina L.V., Mikheeva T.M. Kovalevskaya R.Z., Veres Y.K., Zhukova T.V., Medvinsky A. B., Rusakov A. V., Nurieva N. I., Radchikova N. P., Chakraborty A. Relations between variations in the lake bacterioplankton abundance and the lake trophic state: evidence from the 20-year monitoring. Ecological Indicators, 2019, vol. 97, pp. 120-129.

Conflict of interests: The author declares no information of obvious and potential conflicts of interest related to the publication of this article

Received: 24.08.2020

Accepted: 28.05.2021

Marina O. Morozova

Engineer, Post-graduate student, Institute of Natural Resources, Ecology and Cryology of the Siberian Branch of the Russian Academy of Sciences, Chita, Russian Federation, ORCID: 0000-0001-8152-8285, e-mail: marina_matveeva94@inbox.ru 